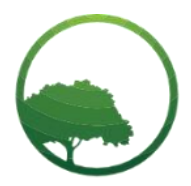

Research in Business \& Social Science

IJRBS VOL 10 NO 8 ISSN: 2147-4478

\title{
Talent management: A 'recipe' for public service delivery in the fourth industrial revolution
}

\author{
(D) Elvin Shava ${ }^{(a) *(10)}$ Shikha-Vyas Doorgapersad ${ }^{(b)}$ \\ (a) Post-Doctoral Research Fellow, School of Public Management, Governance \& Public Policy, University of Johannesburg, South Africa \\ (b) Professor, School of Public Management, Governance \& Public Policy, University of Johannesburg, South Africa
}

A R T I C L E I N F O
Article history:
Received 29 November 2021
Received in rev. form 20 Dec. 2021
Accepted 22 December 2021
Keywords:
Talent Management, Public service
delivery, Fourth Industrial Revolution,
Local municipalities
JEL Classification:
O38; O39; Z00

\begin{abstract}
A B S T R A C T
The article was based on an interpretive paradigm, which adopts a qualitative desktop review approach. Various document sources that inform $4 I R$ and talent management within the local government context in South Africa were employed. The two cities of Johannesburg and Ekurhuleni were used as case studies to examine their talent management strategies in the 4IR. The analysis of documents has shown that the 4IR can enable accelerated delivery of services; increase access to services; improve community participation; and more significant social accountability. Nevertheless, some municipalities in South Africa do not have enough resources and skills capacity to implement ICT/4IR measures to improve services; hence managing talent in key technical jobs has become an impediment. The absence of institutional readiness among local municipalities is a huge deterrent to managing talent needed to drive service delivery in the 4IR. The study concludes that to achieve efficient public service delivery within the $4 I R$, local municipalities should retain talent to manage the digital technologies that demand skilled expertise. The article recommends the government develop policies that offer guidance to local municipalities on managing specified sets of talents that are deemed crucial to enhancing socio-economic development in the 4IR.
\end{abstract}

() 2021 by the authors. Licensee SSBFNET, Istanbul, Turkey. This article is an open access article distributed under the terms and conditions of the Creative Commons Attribution (CC BY) license (http://creativecommons.org/licenses/by/4.0/).

\section{Introduction}

Talent management is a broad phrase with no universal definition. It depends on the context and purpose in which it will be used. The interchangeable use of talent management with succession planning and human resources planning triggers further controversies. Other scholars explain talent management through various approaches, including competency, individual strength, giftedness, high potential, and high performers (Meyers et al., 2013:305; Tetik, 2016:41). Talent management is described by Gallardo et al. (2020:457) as all activities that include planning, identification, engagement, retention, deployment, and developing the individual (staff) training, development, and education need systematically. Talent management is essential for attracting, motivating, and retaining productive employees in the public sector (Mehale et al., 2021). Therefore, talent management should be institutionalised in municipal planning to enhance efficiency in public service delivery.

Nevertheless, the chronic shortage of skills has been a barrier to effective service delivery in South African municipalities (Sebola, 201:181; Van Dyk, 2013:62). There has been a slow implementation of talent management programmes to improve the competence of officials to accelerate service delivery in communities. Gibson \& McKenzie (2011:107) hold that skills shortage emanates from poor talent management that triggers massive scale brain drain in South Africa. Statistics South Africa (2015) laments that skills deficit had been caused by the emigration of qualified minorities to other developed countries, decreasing the pool of skills due to affirmative action's unintended effects. The recent Critical Skills Survey (2020/21) conducted by Xpatweb indicates the deficit of

\footnotetext{
* Corresponding author. ORCID ID: 0000-0001-8721-4666

(C) 2021 by the authors. Hosting by SSBFNET. Peer review under responsibility of Center for Strategic Studies in Business and Finance.

https://doi.org/10.20525/ijrbs.v10i8.1504
}

Citation: Shava, E., \& Doorgapersad, S. V. (2021). Talent management: A 'recipe' for public service delivery in the fourth industrial revolution. International Journal of Research in Business and Social Science (2147- 4478), 10(8). 
skills in South Africa that may force the business sector to import the skills globally to respond to the international pressure posed by the 4 IR.

Although talent management is a grey field for academic research in public sector human resources management, a dearth of empirical research exists in South Africa. This is because studies conducted in the past were not embedded in Public Administration theory or practice; hence, they fail to clarify or suggest ways in which talent management can be practiced within the local government context. This article advocates for talent management as a recipe for effective service delivery. However, no studies have yet documented how talent can be managed using digital technologies in a municipality context in South Africa. Considering this gap, this article aims to reiterate the need to retrain, manage and develop skills of public officials, aligning them to the demands of 4IR, which is crucial for public service delivery. To address this vacuum towards attaining the 4IR, the article utilises the Human Capital Theory as it helps to respond to the following questions:

i. Are municipalities in South Africa ready to embrace the 4IR?

ii. Do municipalities need to amend their talent management policies to meet the demands of 4IR?

iii. Do local municipalities in South Africa have the institutional capacity to execute talent management programs for effective service delivery in the 4IR?

A qualitative method was adopted to employ documents related to talent management, digital technologies, and public administration as data collection tools to address the questions above. Manson (1996:4) states that a qualitative research approach outlines how people's lives, behaviour, and interactions are used to understand, examine, or construct the world. Documents employed had the proper meaning as they were carefully scrutinised to reach conclusions for this article. Examples of how talent management was used to enhance the skills capacity of public officials were drawn from the two cities of Johannesburg and Ekurhuleni in the Gauteng province of South Africa. These two metros have undertaken steps to enhance talent management to keep abreast of the changes triggered by the 4IR in South Africa.

After the introduction, the first section focuses on the theoretical perspective (Human Capital Theory) for talent management in the 4IR, followed by a conceptual and contextual overview of talent management in South Africa. The third section reviews the challenges of talent management in municipalities in the 4IR, followed by talent management in the 4IR. The fifth section discusses talent and skills management in the 4IR in municipalities, followed by the importance of talent management in the 4IR. The seventh section discusses findings looking at the readiness of two South African municipalities towards embracing talent management approaches in the 4IR. The last section concludes, offers recommendations, including limitations and direction for further studies.

\section{Theoretical Perspective: Human Capital Theory for Talent Management in the 4IR}

To understand how local government in South Africa can embrace the 4IR using talent management practices, the researchers adopted the Human Capital Theory (HCT). Schultz (1961:9) noted that human capital traced its roots to the early 1960s when the theory included knowledge, skills, and abilities of the people employed in an organisation. Since this description of human capital excludes value and investment in human skills, Schultz (1981:21) later improved the definition by stating that human capital includes "all human abilities that either innate or acquired. For Mincer (1962:550), the human capital theory includes schooling and education that prepare the labour force. Distinctively Becker (1964) adds that it is "a form of investment by an individual in education to the point to where returns in extra income are equal to the costs of participating in education' interestingly year later," Becker (1993:3) view human capital as the integration of knowledge, information, ideas, skills and health of individuals. By adding an extra aspect of health, Becker departed from the initial understanding of human capital and included health to understand the feelings and experiences of employees in organisations regarding talent management

Todaro (2011:365) further claims that the HCT assumes that an individual capacity to learn is off and has a comparative value to other resources that are employed in the processing of producing goods and services. The scholar's reasoning is drawn from the idea that when educated individuals work, they tend to make income and increase productivity for the benefit of society. Supporting the need for skills and knowledge in municipalities in the 4IR, Beckers (1993:19) reiterates that schooling raises earnings and productivity by providing knowledge and skills to address challenges. Given the complexity of adopting technology and models within the public sector, Becker's ideas relate to the need by local municipalities in South Africa to ensure that skills are retained and managed through training and other performance appraisals to enhance efficiency in service delivery.

From Becker's understanding of HCT, researchers draw inspiration to assess how local municipalities in South Africa can manage employees' talent, skills, and knowledge as critical components for improving service provision in the 4IR. Previous arguments point to a skills gap in local municipalities and the need for think tanks, innovators, and employees in various fields. Therefore, the authors argued that the HCT could be strategically employed in municipalities to develop skills and talents as imperatives for spearheading the 4IR. The core argument rests in the fact that a skilled, knowledgeable, and competent local government workforce can drive change in communities using modern digital technologies that improve communication with citizens, increase transparency and accountability, and liaison with investors and stakeholders. Since the 4IR is anticipated to change how humans' function and work, it remains a prerogative for local municipalities to prepare public officials to embrace the changes triggered by the 4IR wave while retaining the skills and talents in various sectors. 


\section{Conceptual and contextual overview of talent management in South Africa}

The concept of talent management (TM) sent scholars into loggerheads as myriad controversies, assertions, and debates were being forwarded. However, old literature (Boudreau \& Ramstad, 2005:129; Cappelli, 2008; Lewis \& Heckman, 2006:139) did little to claim the concept and position the term in the theoretical development. A contemporary body of literature on public human resources management argues that talent management is a human resources aspect with a sustainable competitive advantage (Gallardo et al., 2020:458; Collins et al., 2019:541). Similar studies indicate that to have a competitive advantage, an organisation should have capabilities and resources aligned to talented individuals that constitute an organization's human capital (Cheese et al., 2008).

In literature, the terms "talent management," talent strategy," "succession management," and "human resource planning" are often used interchangeably. As alluded previously, TM may mean different things, although common belief among scholars (Guthridge \& Komm, 2008; Ringo et al., 2010) is that TM can be regarded as a process of hiring, training, and integrating new employees, as well as developing and retaining current employees and attracting competent workers in an organisation. In organisations, TM is focused on developing strategy, identifying talent gaps, succession planning and recruiting, selecting, educating, motivating, and retaining talented employees through various initiatives. In this article, therefore, TM is viewed from the angle of skills development and retention, whereby officials in local government are capacitated with the necessary skills to utilise digital technologies to improve service delivery in the 4 IR.

Talent management practices in South Africa are inclusive of the entire workforce; hence the legislation and regulations in the public sector are geared toward promoting the growth of all personnel (Theys \& Schultz, 2020:3; Van Dijk, 2008:522). This reasoning stems from the fact that developing and retaining talents in public organisations require enabling legal frameworks to be established as support mechanisms. Nonetheless, Thunnissen (2016:57) cautions that talent management does not always imply having the necessary brainpower, knowledge, skills, experience, mental, or physical traits, but instead being innovative and achieving something higher, more complicated, or unexpected in the future. To tap into the benefits of the 4IR, municipalities are inclined to cultivate talent management programmes that close the skills deficit gap. Although increasing the talent pool is part of the legal requirement to train public officials in some municipalities, recent research points to inefficiency gaps in public service delivery which is a step back towards embracing the 4IR (Theys \& Schultz, 2020:3).

Since controversies surround the term talent management, this article advocates for local municipalities in South Africa to integrate the term in their municipal Integrated Development Plans (IDPs) and skills planning programmes. This is crucial for enabling public officials to be retrained in ICT and 4IR related skills that improve service delivery. Furthermore, the generic understanding of talent management in the public sector entails the construction of a competent workforce to realise the vision and mission of an organisation. The rise of competitiveness in the international world of business exposes businesses to cutting-edge technologies, necessitating the development of new talent and skills for long-term success (Shava \& Hofisi, 2017:209). Consequently, the cultivation of talent management lies at the cornerstone of the public sector in the 4IR (Aina \& Atana 2020,1). Veladat \& Navehebrahim (2017:1052) indicate that talent management aims to achieve organisational objectives and improve service provision in communities. Due to the proliferation of digital technologies in the 4IR, the researchers argue that governments in developing countries need to embrace modern digital technologies to accelerate public service delivery. Talent management, therefore, remains the key focus to ensure that employees meet the desired competence to utilize digital technologies to improve productivity and public service provision.

\section{Challenges of Talent Management in municipalities in the 4IR}

The lack of talent management in local government and failure to invest in human capital increases brain drain and triggers service delivery backlogs (Chand, 2019:6). The failure by the local government to map talent is also attributed to the brain in many developing African countries as skilled employees emigrate for greener pastures, mainly in developed states such as Canada, the United Kingdom and the United States (Latukha et al., 2021:1). In South Africa, Bohlmann (2010:1) argues that the government's inability to develop, recruit and keep adequate levels of human capital in the country has been causing severe skills shortage. The absence of talent management is attributed mainly to declining educational systems, inadequate resources, training system weaknesses, and cyclical increases in employment in many sectors. Some of the qualification's officials possess in local municipalities are hard to manage as they are not directed or match a specific job description. The haphazardness in skills triggers skills shortage, as officials are employed in the field where they are not specialists, thereby causing deficiencies in service delivery. Sutherland (2019:6) further noted the lack of engagement among state departments, bureaucracy, absence of necessary legal and institutional framework, minimal investment, and administrative and political processes as some of the challenges affecting municipalities from implementing talent management in the 4IR.

\section{Talent management in the Fourth Industrial Revolution}

The predictions made by Schwab (2016) regarding the significant impacts of the 4IR have triggered a transformation in various public sector organisations globally, as the need to groom new talent became evident to keep abreast of the enormous technological developments. The Fourth Industrial Revolution (4IR) refers to integrating digital technologies, including artificial intelligence, 3D printing, quantum computing, robotics, blockchain including the internet of things (IoT). The interaction of these technologies may transform the way humans live, work and relate to one another in the universe. Globally as noted in the study of Deloitte Global 
(2021:5), millions of young men are unemployed or underemployed simply because the available jobs do not match the skills they possess. The growing skills mismatch (Shava \& Maramura, 2016:94) with what job seekers have and the industry demands may primarily affect public organisations as digital technologies in the 4IR seek to revolutionalise jobs, society, and economies, including people's lives. The 4IR is assumed to impact customer expectations, collaborative innovation, product enhancement, including organisational reforms. Public organisations in South Africa are expected to be ready to navigate the changing service delivery arena where various digital technologies can be used to report to citizens, deliver services and sustain public sector business. However, current debates regarding automation in South Africa are centred around the fear that digital technology (machine learning, artificial intelligence, and robots) will destroy more jobs than they intend to create (Magwentshu et al., 2019:8; Shava \& Hofisi, 2017:205). Although this may not be the case, global evidence indicates that digital technologies may create more jobs if skilled labour can fully utilise machines to enhance productivity. The article emphasises the term 'skilled labour' as it means employees with the expertise and training to carry out strenuous physical and mental routine jobs (Investopedia, 2021:1). To attract, train, and retain employees' skills, organisations implement talent management processes for improved individual performance and organisational productivity.

\section{Talent and skills management in the Fourth Industrial Revolution in municipalities}

Deloitte Global (2021) study resulted in many questions being asked by various researchers in talent management. What skills are supposed to be retained, managed, or developed in the 4IR by public sector organisations? Is the 4IR relevant to local municipalities? These questions are essential as they help people understand various misconceptions regarding the 4IR as the technological revolution alone without considering other necessary skills business and the public sector should manage to enhance efficiency and productivity. To begin with, soft skills that relate to personal attributes, social, communication skills are vital as they inform interpersonal relationships and interactions people have with others (Sutcliffe \& Bannister, 2020). This skill is critical in local municipalities in South Africa as it guides the public procurement processes where deals are negotiated with service providers to accelerate service delivery. The absence of such a skill can trigger many challenges in municipalities such as overpaying, underpaying service providers, and lack of investment in municipal infrastructure, among other vital service delivery imperatives. Secondly, technical skills related to capabilities and knowledge to conduct specialized tasks are crucial as functions related to computer programming, project management, coding, and financial management demand such skills. For a municipality, for instance, to survive cyber-attacks, ICTbased employees and digital transformation specialists must ensure that finances are safeguarded, that software is developed, and becomes resilient towards effective public service delivery (Sutherland, 2019:4). The third skill that needs to be developed in municipalities is entrepreneurship. This skill informs the knowledge and competence in creating an innovative workforce with ideas to enhance productivity (Ogunlela \& Tengeh, 2021:91). In a local government, such a workforce can be industrious, innovative, resourceful, optimistic and risk-takers willing to initiate development programmes that generate revenue for municipalities towards improving public service delivery in the 4IR. Analysing these three skills points to various skills deficit gaps encountered in South African local municipalities that need to be filled to attain efficient service delivery.

Although local municipalities in South Africa may draw inspiration to utilise digital technologies to enhance service delivery, Sutherland (2019:2) argues that as a country, South Africa is not well-positioned to activate the 4IR. The authors' argument emanates from the agri-based economy South Africa depends on, including mining and the informal sector (Sutherland, 2019:2). These three sectors driving the economy are associated with high unemployment, skills shortage, especially in the mining sector. It can be argued that, although soft skills, technological and entrepreneurial skills may help improve public service delivery in South African municipalities, increased investment in human capital and interdepartmental coordination and planning are required while managing existing talent and retaining a skilled workforce. This can help local municipalities reengineer local economies using digital technologies that increase efficiency and help create employment in the digital space and other entrepreneurship projects.

\section{Importance of Talent Development in Municipalities in the 4IR}

Davies \& Davies (2010:418) state that developing skills and learning are essential elements for the talent-focused organisation in talent development. Achieving an efficient organisation demands employees to learn new ways and procedures that help enhance performance management (Mohammed, et al., 2019:24). To fully explore the benefits of the 4IR, municipalities need to employ talent development programmes since employees learn various skills to improve service provision (Bhatia, 2015). To ensure that such programmes are conducted in a municipal setting, talent management should involve human resources, professional learning to produce a strategic impact in an organisation (Mohan, 2015:56). Talent development, therefore, includes developing leaders via processes such as coaching, feedback, training, mentoring, and challenging employees (Moayedi \& Vaseghi, 2016,16; Ibeh \& Debrah, 2011:42). In an organisation, employee development must be informed by various talent development programmes such as skills training, workshops that are vital for enhancing the competence and skills of municipal officials towards attaining the 4IR.

Managing talent in technical ICT and digital fields can also help transform and realign the economy of South Africa with local communities. Drawing exciting lessons from other African countries such as Rwanda and Ethiopia, technologies brought in the 4IR are being embraced to transform the economy, society, and labour market. Therefore, municipalities in South Africa may need to redirect their efforts toward advancing infrastructure that supports 4IR technologies while the national government increases funding towards skills development and management. 
Whereas the Skills Development Act of 1998 in South Africa provides a roadmap to revamping the skills of public sector officials, many obstacles are being encountered in local municipalities and these can adversely affect public service delivery in the 4IR. However, the National Development Plan (NDP) Vision 2030 gives hope. It projects Information Communication Technology (ICT) as a vehicle for regenerating the country's economy, promotes youth inclusion in economic affairs, and targets improved livelihoods. By embracing ICT, arguably, local government in South Africa can actively participate in the 4IR by embracing talent management programmes that effectively prepare public officials to utilise modern digital technologies towards effective service delivery. Although local municipalities seek to align the 4IR with the government frameworks such as the NDP Vision 2030, recent literature has shown that the public sector in Africa experiences various challenges concerning talent management which may trigger adverse effects towards sustaining organisation performance in the 4IR (Aina \& Atana, 2020:2; Farndale et al., 2014:157).

\section{IR readiness of municipalities}

4IR, according to Cloete and Moloko (2019:5), can enable: "accelerated delivery of services; increase access to services; improve community participation, and more significant social accountability only if we implement and adopt 4IR". However, different scenarios exist in this situation. Some municipalities do not have enough resources to implement ICT/4IR measures to improve services. Some municipalities are on the road to becoming smart cities but encounter challenges like lack of training and awareness. The article is based on the desktop studies of two metropolitan municipalities to substantiate the argument. The future studies will include other municipalities. The continuous research in this manner will form part of comparative longitudinal studies.

Since "the demise of the apartheid regime, South Africa experienced a proliferation of violent service delivery protests characterised by different forms of upheaval in an epoch not perpetuated by racial divides but owing to government failure to provide sustainable services to its citizens" (Mkhabela, 2013:5). Haycock (cited in Maseko and Vyas-Doorgapersad, 2018:177) acknowledges the government's contemporary service delivery strategies, which portray a diversion from traditional approaches to rendering public services. ICT, e-governance, e-services, e-administration, smart city, and 4IR are alternative service delivery mechanisms that municipalities must embrace. However, research conducted in the City of Johannesburg by Maseko (2018) explores that respondents were unaware of "e-government services in the municipality and that training programs are being provided to ensure citizens understand the role of e-services (Maseko, 2018:113-114).

Another study conducted by Ncamphalala in the City of Ekurhuleni in 2019 explores the exact nature of challenges, whereby respondents were unaware regarding "any knowledge of ICT; and availability of training programmes to enable citizens to become conversant with ICT towards attaining smart service delivery (Ncamphalala, 2019: 97-98). The common element from these research works show that even the two metropolitan municipalities have implemented digitalised means to provide services, the community members are not trained to utilise these services. The lack of awareness regarding the availability of smart initiatives for seamless services is rampant. In terms of talent management within these municipalities, the authors share the concern that in the era of 4IR the talent management needs to include external clients for adequate utilisation of digitalised services. This situation is challenging, as stressed in an official document of Kwadukuza municipality (n.d.:5), highlighting the absence of talent management in local municipalities that primarily affect HR value creation processes and trigger poor service delivery in the public contrast to the private sector. Failure to design talent management practices resulted in the inadequate investment in skills to meet the globalised demands of work processes. The document further highlights that "within the localised perspectives of talent management value chain, there is still fragmentation and lack of inconsistency in local municipalities. This is because corporate culture and systems within the local government have not promoted talent management. This adversely affects municipal development as the absence of talent management culture aligned to stakeholder demands rigger incompetency as the learning development is not aligned to competency/skills framework" (Kwadukuza municipality (n.d.:14). This was confirmed by another study conducted by Kemp in 2020 seeking information on human resource (HR) measures to appoint skilled and competent staff. The study compiled the information from the CoJ report (2018:213) and highlighted that "human capital management programs and projects enhance the CoJ's recruitment process". However, it needs to be ensured that to implement these programs and projects, "personnel have the necessary skills and abilities to provide the services" (CoJ, 2018: 213 also refer to Kemp, 2020:55). The authors suggest that in this regard, the HR Manager and the Events Manager need to work together to organise workshops to realise the implementation of ICT/4IR interventions, accommodating both internal and external clients and stakeholders.

4IR is linked to smart city interventions of municipalities. Municipalities that subscribe to smart city thinking provide strategies that benefit people's lives for improved urban living. Reinforcing the utilisation of digital tools and ICTs, Internet of Things (IoT) through 5G, artificial intelligence, including automation of repeatable tasks, help achieve smart city agenda (Copping et al., 2018 in Ncamphalala, 2019). By growing and retaining talent, municipalities in South Africa can attain a well-connected smart city, utilise ICTs, and has sophisticated infrastructure based on modern architecture to help solve urban service delivery problems. As observed by Caragliu et al., (2009: 45), such smart cities have an adequate investment in infrastructure, social capital and human investment that promote ICT use for sustainable economic growth and improved standards of living for the people (Maseko, 2018:64). Other studies perceive a smart city that utilises modern technology to promote citizen empowerment through sustainable technology development projects. In this vein, it is worth considering that municipalities require talent management to utilise, establish, implement and maintain smart city initiatives. 
The local government in South Africa has changed in the past two decades as more people can access essential services at any time in the country's history. This is commendable progress despite the social ills inherited from the past that hinder progress and transformation. The development of modern technologies championed by the 4IR (Shava \& Hofisi, 2017) requires local government to restrategise and align its governance structures towards improving service delivery. New ways of thinking and techniques are necessary to address the inherited problems and the present woes facing communities in South Africa (SALGA, 2018, in Ncamphalala, 2019: 57-58). This approach is substantiated by the views of the South African Local Government (SALGA) Chief Executive Officer (CEO) Xolile George, who stressed the need for adopting a holistic approach that can be aligned to 4IR since innovative thinking from previous experiences require infrastructural development in local government to attain the benefits of the 4IR (George, 2021:1). However, to achieve the necessary level, building the capacity of employees in ICT and establishing ICT infrastructure remain crucial to meeting the competencies demanded by the 4IR. In this case, concerns hang around the question that states, "Are South African municipalities ready to embrace the 4IR? Ncamphalala (2019) argues that the recent spending cuts in both metros could affect infrastructural development, derailing these metros from becoming the champion of 4IR through ICT use. Attaining the digital revolution spelt by President Cyril Ramaphosa may need to revisit talent development strategies to see their alignment to 4IR demands.

The CoJ (2016) implements the smart city initiative to enhance public satisfaction and create a happy citizenry; accelerate industry development, service orientated government, and a long-term stable society to be part of this revolution. It also aspires to establish a Unified Management Model that connects government, business, citizens, and public products and services. Public products such as general infrastructure and utilities, health, the environment, transportation, educational facilities, and resources are also part of the plans. Administrative services, civil applications and complaints, crisis management, and rescue and recovery services are all examples of public services (CoJ, 2016; Maseko 2018:124). The CoJ projects itself as the smart city of tomorrow with smart municipal management, rendering smart livelihoods for the peoples, social utilities, low-cost green energy, smart care and protection of citizens including a digital industry (CoJ, 2016; Maseko, 2018:124).

The CoJ's has formed a partnership to realize the vision of a smart city that integrates 4 IR "The Gauteng City-Region Observatory (GCRO) is a collaboration between the University of Witwatersrand (Wits), the University of Johannesburg (UJ), and the Gauteng provincial and municipal governments. Its mission is to assist in making decisions that improve urban life for everyone." (, University of the Witwatersrand 2019a). In addition, the Fak'ugesi African Digital Innovation Festival was founded in 2014 by Tshimologong and the Wits School of Arts' Digital Arts Department. The spirit of collaboration in appreciation of all things digital continues as the City of Johannesburg's Smart City Office recognizes the enormous influence of African and South African culture on actual innovation in the 4IR, limited to local circumstances (University of the Witwatersrand, 2019b).

The CoE, on the other hand, has partnered with Bytes Technology Networks (BTN) in a project worth about R12 million to upgrade and replace much of its existing networking infrastructure (Carroll, 2005:1). The goal is to establish a first-class network suitable to house the rendering of e-services to the citizens (Pillay, 2005:1). This can be enabled by the developed new networking infrastructure that has high speed, capable of offering multi-service including the state of art voice and data and video technology infrastructure. Due to such ICT development, a Customer Innovation Award in the Digital Transformation category was received by CoE at the Software AG's Innovation World 2013. The Software AG (2013:1) confirms that Ekurhuleni Municipality won the award for using Software AG Technology to enhance and speed up service provision to citizens of South Africa.

Young people can receive free digital training from the CoE to help them gain confidence when using technology. They will design and create mobile applications and games and websites, thanks to a free online Microsoft Information Communication Technology (ICT) training curriculum. The training program, which began in mid-August, is open to young people aged seven to twenty-one in Ekurhuleni. The youth will learn basic computer skills, digital literacy, creative coding, and app studio and touch development as part of the curriculum (Mathebula n.d.:1).

The CoJ also has adopted more remarkable strides in the 4IR as it collaborated with Google South Africa to promote the development of digital skills through training. The content of the courses is available free of charge at centres via an e-learning portal: "COJELEARNING" - or online via http://www.cojelearning.org.za. The city's libraries introduced e-classrooms to upskill the youth and community members with digital skills relevant to today's trends. The City's e-classrooms are intended to encourage youth employability, create employment opportunities for youth and reduce technology disparities despite the social background citizens emerge from (CoJ, 2018).

Resonating with the vision of the President, the Gauteng Premier also aims for "Gauteng to become a 'hub of Fourth Industrial Revolution' skills" (Walker, 2019). The Premier reiterated the need to invest in internet connectivity to improve GDP by 1,5\%. Also, enhancing public service, generating new industries and offering new platforms for small businesses to participate in the mainstream economy marked the Premier's State of Province Address (SOPA). For the past decades, the Gauteng city region has been established as a smart and techno-savvy initiative with an innovation ecosystem encompassing Gauteng Innovation Hub, research institutes, public universities, and private sector centres of innovation eKasi Labs. As affirmed by the Business Technology Media Company (2019), plans are in place to expand the infrastructure and widen the scope of the offering of the Gauteng Innovation Hub to resuscitate thereof, growing it into Africa's Silicon Valley that enhances the development of the digital economy. The Premier projected digital skills empowerment of 1million youth people from this program, which is fundamental for realising Gauteng as the Silicon Valley 
of Africa (Ngatane, 2019). All these interventions are meant to develop talent amongst the youth who is the receiver of municipal services as residents and may also be the future employees of municipalities. To fulfil this aim, the SALGA organised the 2ND Annual Local Government Talent Management Seminar from 30th - 31st January 2020 under the theme "Building municipal resilience for complexity and change from an integrated talent management perspective" (SALGA, 2020:5).

Most importantly, the conference discussion was centered around developing the skills capacity of employees so that they make a difference instead of limiting them to job profiles based on policy or traditional viewpoints (SALGA, 2020:5). To strengthen the capacity of local municipalities, the discussion also embraced the vast opportunities new technologies might offer in the 4IR. As a way of practicalising the debate, key speakers and panellists advocated for the collaboration of municipalities with training institutions to foster skills training into the talent management practices in the local sphere (SALGA, 2020:5). These initiatives can only be assessed in the coming future and form part of future publications.

\section{Conclusion}

The article draws its analysis from the Human Capital Theory, which dictates the need to invest in skills in local government as a prerequisite for driving change the 4IR. The documentary evidence from Johannesburg and Ekurhuleni revealed some of the challenges that may derail the implementation of talent management programmes as a responsive strategy for exploring the new technologies, models and concepts offered by the 4IR. These include lack of ICT skills, rapid urbanisation, poor infrastructural development, lack of collaboration, poverty, unemployment and effects of COVID-19 pandemic.

Furthermore, the analysis of the two metros revealed no 'one size fits all approach to talent; management now identifies skilled personnel that can influence service provision in the 4IR. This is because available skills development programmes are conducted per department when there is a need and to achieve a particular objective or complete a specific project or task. This gap in the two metros shows the need to revise existing skills development programmes to ensure that they align them to the expectation of the 4IR; hence upgrading the capacity of public officials is key to enhancing public service delivery. For talent management to become the 'recipe' for effective service delivery, these gaps in infrastructure, skilled personnel, enabling policy and technology environment are important.

Based on the analysis of main findings, the article offers the following recommendations to enhance talent management in the 4IR:

Political level: At the institutional level, municipalities need to incorporate the strategic areas recommended by the Presidential Commission held on 06 August 2020 in South Africa. It encourages local municipalities to focus on human capital, artificial intelligence, the provision of data to enable innovation and 4IR infrastructure (The Presidency, 2021:1). These recommendations are essential in their talent management policy, ensuring that human capital is digital-competent, the IT unit is equipped with the implementation of artificial intelligence-based service delivery mechanisms, the availability of technological resources, and IT infrastructure offers seamless services to community members. However, it is equally essential that municipalities invest in ICT/4IRbased talent management, so personnel can incorporate, integrate and implement 4IR-based services through the IT infrastructure.

Policy level: The Department of Communications and Digital Technologies (DCDT) has been tasked with the development of a Presidential Commission 4IR Strategic Implementations Plan (PC4IR SIP) to realise the recommendations of the PC4IR Report (RSA: Department of Communications and Digital Technologies (DCDT), 2021:2) that will be applicable for all national departments. The vision of the PC4IR Strategic Implementation Plan includes fostering an internationally competitive shared and inclusive economy that has the technological capability and production capacity championed by citizens to drive the economy in the 4IR (DCDT, 2021:2). Talent management is highlighted in the vision under "driven by people". These people need to be equipped to realise the vision of PC4IR. As noted by the DCDT (2021:11), this demands all municipalities adopt the National Digital and Future Skills Strategy to impart digital skills to citizens by upskilling and reskilling include continuous learning, which is imperative for reducing the digital skills divide. A setback in promoting talent management through digital skills training was noted by Sutcliffe and Bannister (2020:8). They observed the absence of 4IR in local municipalities' medium- and long-term planning. To close this gap, COGTA and National Treasury need to design a digital skills policy paper that spells the expectation of local municipalities regarding talent management in the 4IR. Providing guidelines can assist local municipalities with what is required of them. They will align their policies and skills to 4IR demands, including existing legal frameworks like the National Development Plan Vision 2030.

Municipal level: There is a need to incorporate talent management as an integral part of HR practices; organise workshops on talent management in the 4IR era to develop dialogue, awareness and strategies to capacitate municipal personnel and stakeholders; perform need assessments to find competency gaps related to ICT/4IR skills; establish a 4IR research unit in municipalities to assess the level of implementation of PC4IR recommendations and propose solutions through comparative research, and set a budget to improve ICT/4IR infrastructure and processes. In addition, municipalities need to develop e-government platforms for service delivery. However, both municipal employees and community members require adequate capacitation to utilize services available via eplatform.

Organisational Level: The incorporation of 4IR based talent management with HR practices, focusing on human capital in an automated digitalised era of work processes, is fundamental. Analysis of literature has shown that the absence of capacity-building investment in human capital promoting talent in ICT/4IR processes may result in the loss of jobs to automated processes. As noted 
by SALGA (2020: 25) municipalities are expected to develop employees' competencies in digital skills, making them managers and leaders of digitialised work processes. Developing a "Digital leader [who]: is not afraid to take risks when implementing policies/procedures that transform an organisation towards a digital future is needed in local government. Such a leader must be an innovator who thinks ten steps ahead is eager to create a continuously learning organisation (SALGA, 2020:25).

Stakeholder level: COGTA, National Treasury (NT) and SALGA should facilitate a process to reassess the skills needed at a local level through more excellent knowledge sharing on the opportunities in the transition and during the 4IR (Sutcliffe and Bannister 2020:8). COGTA should encourage municipalities to include digital strategies in their IDPs to foster talent management skills in the 4IR (Sutcliffe and Bannister, 2020:9). The incorporation of human capital in the PC4IR and the obligation for municipalities to adopt the recommendations made by the DCDT support the theoretical framework of human capital theory used as a scaffold for the article.

\section{Limitations and Future Research}

4IR is an emerging trend and countries/organisations/institutions are finding ways to embrace this trad in their work processes. Therefore, the literature related to 4IR-driven talent management is not widely researched. A few articles or documents can only assist with fragments of information. This has limited the authors to finding relevant information for a conceptual framework. Various organisations and municipalities are organising workshops and consultation sessions to discuss the issue of 4IR, and some are also discussing the role of talent management in 4IR. These documents are only available as draft documents or workshop outcomes requiring further discussions to draw appropriate recommendations for implementation. Wherever recommendations are finalised, the implementation level of such recommendations is still underway. The implementation gaps, challenges and level of impact will form part of future research works.

Future studies will also include various municipalities incorporating talent management in line with ICT/4IR demands. The future studies will then be of comparative longitudinal studies to assess the integrated talent management strategies in the local, district, and metropolitan municipalities and their impact on the delivery of services.

\section{Acknowledgements}

The authors acknowledge the School of Public Management, Governance and Public Policy within the College of Business \& Economics, at the University of Johannesburg for relevant affiliation support.

Author Contributions: Conceptualization, E. S; methodology, SVD ; validation, ES.; formal analysis, SVD and .ES.; investigation, E.S.; resources, ES.; writing — original draft preparation, ES. and SVD; writing - review and editing, ES.; supervision, SVD; project administration, ES.; funding acquisition, SVD. All authors have read and agreed to the published version of the manuscript.

Institutional Review Board Statement: Ethical review and approval were waived for this study, due to that the research does not deal with vulnerable groups or sensitive issues.

Data Availability Statement: The data presented in this study are available on request from the corresponding author. The data are not publicly available due to privacy.

Conflicts of Interest: The authors declare no conflict of interest.

\section{References}

Aina, R.A., \& Atan, T. (2020). The Impact of Implementing Talent Management Practices on Sustainable Organisational Performance. Sustainability, 1-25. https://doi.org/10.3390/su12208372

Ayentimi, D. T. \& Burgess, J. (2018). Is the fourth industrial revolution relevant to sub-Sahara Africa? Technology Analysis \& Strategic Management, 1-12. https://doi.org/10.1080/09537325.2018.1542129

Becker, G.S. (1993). Nobel lecture: the economic way of looking at behaviour. Journal of Political Economy, 101 (3), 385 - 409.

Becker, G.S. (1964). Human capital: a theoretical and empirical analysis, with special reference to education. New York: Colombia University Press.

Bhatia, A. (2015). An investigation of key strategies, practices and challenges facing talent management in IT industry: an exploratory study in India and Ireland, master thesis, Business Administration, Dublin Business School, Dublin

Bohlman, H.R. (2010). The Macroeconomic Impact of Skilled Emigration from South Africa: A CGE Analysis. Melbourne: Centre of Policy Studies, Monash University.

Boudreau, J.W., \& Ramstad, P.M. (2005). "Talentship, Talent Segmentation, and Sustainability: A New HR Decision Science Paradigm for a new Strategy Definition", Human Resource Management, 42, 129-36. doi.org/10.1002/hrm.20054

Buchem, I. (2014). Learning and Diversity in the Cities of the Future. https://books.google.co.za/books?id=AFUhBwAAQBAJ\&dq.

Business Technology Media Company, (2019). Gauteng's 4IR advisory panel in the works. Retrieved from: https://www.itweb.co.za/content/Olx4z7kgY4r756km/

Cappelli, P. (2008). Talent on Demand, Boston, MA, Harvard Business School Press.

Caragliu, A, Del Bo, C., \& Nijkamp, P. (2009). Smart Cities in Europe. 3rd Central European Conference in Regional Science CERS. http://www.inta-aivn.org/images/cc/ Urbanism/background\%20documents/01_03_Nijkamp.pdf

Carroll, C. (2005). Gauteng`s largest Metro, Ekurhuleni, with partner BTN standardises network on Cisco. https://www.itweb.co.za/content/nWJad7baRLGvbjO1

Chand, M. (2018). Brain Drain, Brain Circulation, and the African Diaspora in the United States. Journal of African Business, 1-14. doi:10.1080/15228916.2018.144046 
Cheese, P., Thomas, R.J., \& Craig, E. (2008). The Talent Power Organisation: Strategies for Globalization, Talent Management and High Performance, London and Philidaphia, Kogan Page.

City of Johannesburg (COJ). (2009). Broadband Policy Framework. COJ: Department of Economic Development.

City of Johannesburg. (2015). GCR e-Governance Strategy 2015-2020: Moving from e-Government to e-Governance. Johannesburg: City of Johannesburg Metropolitan Municipality.

City of Johannesburg. (2016). Implementing the Joburg 2040 Strategy, Johannesburg: City of Johannesburg Metropolitan Municipality.

City of Johannesburg. (2016). Smart City: Synthesis. Johannesburg: City of Johannesburg Metropolitan Municipality.

City of Johannesburg. (2018). Jozi joins Fourth Industrial Revolution. https://www.joburg.org.za/

City of Johannesburg (CoJ). (2018). City of Johannesburg Annual Report 2017/18: https://www.joburg.org.za/documents_/Documents/Annual\%20Reports/ 20172018/CoJ\%20Annual\%20Report\%20201718\%20_4\%20March\%202019.pdf.

Cloete, F., \& Moloko, K. (2019). Municipal readiness to implement the fourth industrial revolution: an evidence-based approach. Paper presented at the DHET research colloquium Johannesburg - South Africa 18 - 19 September 2019.

Collings, D. G., Mellahi, K., \& Cascio, W. F. (2019). Global talent management and performance in multinational enterprises: A multilevel perspective. Journal of Management, 45(2), 540-566. https://doi.org/10.1177/0149206318757018

Copping, P. Eskelinen, J., Figueredo, K., Fisher, M., \& Frost, L. (2018). Concept and Models of Digital Governance. http://shodhganga.inflibnet.ac.in/bitstream/10603/105648/10/10_chapter\%202.pdf.

Ibeh, K., \& Debrah, Y.A. (2011). Female talent development and African business schools. Journal of world Business, 46(1), 42-49. https://doi.org/10.1016/j.jwb.2010.05.016

Davies, B., \& Davies, B.J. (2010). Talent Management in academies. International Journal of Education Management, 24(5), 418426. https://doi.org/10.1108/09513541011055983

Deloite Global (2021). Preparing tomorrow's workforce for the Fourth Industrial Revolution For business: A framework for action. https://www2.deloitte.com/content/dam/Deloitte/global/Documents/About-Deloitte/gx-preparing-tomorrow-workforce-for4IR.pdf

Farndale, E., Kelliher, C., \& Hope-Hailey, V. (2014). Work and organisation engagement: Aligning research and practice. Journal Organisational Effectiveness and People Performance, 1(2),157-176. doi: 10.1108/JOEPP-03-2014-0015

Gallardo, G.E., Thunnissen, M., \& Scullion, H. (2020). Talent management: context matters, The International Journal of Human Resource Management, 31(4), 457-473, https://doi.org/10.1080/09585192.2019.1642645

George, X. (2021). SALGA News. The Building Inclusive Green Municipalities (BIGM) International Asset Management Optimization \& Regional Economic Development symposium on Enhancing 4th Industrial Revolution and Smart Governance. Pretoria: SALGA.

Gibson, J., \& McKenzie, D. (2011). The microeconomic determinants of emigration and return migration of the best and brightest: Evidence from the Pacific. Journal of Economic Perspectives, 25(3), 107-128. https://doi.org/10.1016/j.jdeveco.2009.11.002

Guthridge, M., \& Komm, A.B. (2008). 'Why multinationals struggle to manage talent', McKinsey Quarterly, 4, 10-13.

Investopedia. (2021). What Is Skilled Labor? https://www.investopedia.com/terms/s/skilled-labor.asp

Kemp, M.J., \& Vyas-Doorgapersad, S. (2020). Service delivery challenges in Protea Glen, Johannesburg. Africa's Public Service Delivery and Performance Review, 8(1), 1-11. https://doi.org/10.4102/apsdpr. v8i1.368

Kwadukuza municipality. N.d. Building the culture of the integrated talent management value chain in the era of the $4^{\text {th }}$ industrial revolution. http://www.mile.org.za

Latukha, M., Shagalkina, M., Mitskevich, E., \& Strogetskaya, E. (2021): From brain drain to brain gain: the agenda for talent management in overcoming talent migration from emerging markets, The International Journal of Human Resource Management, https://doi.org/10.1080/09585192.2021.1949374

Lewis, R.E., \& Heckman, R.J. (2006). "Talent Management: A critical review", Human Resource Management Review, 16, 139154. https://doi.org/10.1016/j.hrmr.2006.03.001

Magwentshu, N., Rajagopaul, A., Chui, M., \& Singh, A. (2019). The future of work in South Africa Digitisation, productivity and job creation. Mckinsey \& Company. https://www.mckinsey.com/ /media/mckinsey/featured\%20insights/middle\%20east $\% 20$ and $\% 20$ africa/the $\% 20$ future $\% 20$ of $\% 20$ work\%20in\%20south\%20africa\%20digitisation \%20productivity $\% 20 \mathrm{and} \% 20 \mathrm{job} \% 20 \mathrm{creation} /$ the-future-of-work-insouth-africa.ashx

Manson, J. (1996). Qualitative researching. London: Sage Publications.

Maseko, N. (2018). The use of alterative service delivery mechanisms within the City of Johannesburg Metropolitan Municipality. An unpublished mini dissertation. Johannesburg: University of Johannesburg.

Maseko, N., \& Vyas-Doorgapersad, S. (2018). Alternative Service Delivery Mechanisms within the City of Johannesburg Metropolitan Municipality. Administratio Publica, 26(3),170-190.

Mathebula, N. n.d. Ekurhuleni youth get free ICT training. https://www.vukuzenzele.gov.za/book/export/html/3310

Mehale, K.D., Govender, C.M., \& Mabaso, C.M. (2021). Maximising training evaluation for employee performance improvement. SA Journal of Human Resource Management/SA Tydskrif vir Menslikehulpbronbestuur, 19(0), 1-11. https://doi.org/10.4102/sajhrm.v19i0.1473 
Meyers, M.C., van Woerkom, M., \& Dries, N. (2013). Talent — innate or acquired? Theoretical considerations and their implications for talent management. Human Resource Management Review, 23(4), 305-321. doi.org/10.1016/j.hrmr.2013.05.003

Mincer, J. (1962). On the job training: costs, returns, and some implications. Journal of Political Economy, 70(5), 550-79.

Mkhabela, T.V. (2013). Service delivery protests in Bitou Municipality in 2007. Unpublished M Dissertation. University of the Witwatersrand.

Mohammed, A.A., Hafeez-Baig, A., \& Gururajan, R. (2019). A qualitative research to explore practices that are utilised for managing talent development in the higher education environment: A case study in six Australian universities", Journal of Industry University Collaboration, 1(1),24-37. https://doi.org/10.1108/JIUC-02-2019-003

Mohan, M.D., Muthaly, S., \& Annakis, J. (2015). "Talent culture's role in talent development among academics: insights from Malaysian government linked universities", Journal of Contemporary Issues in Business and Government, 21(1), 46-71. https://doi.org/10.7790/CIBG.V21I1.27

Moayedi, Z., \& Vaseghi, M. (2016).The effect of talent management on organisational success", Scinzer Journal of Accounting and Management, 2(3), 16-20.

National Planning Commission (NPC). (2012). National Development Plan. Pretoria: National Planning Commission, Office of the Presidency.

Ncamphalala, M. (2019). The role of ICT to promote smart governance in local governments. Unpublished M Dissertation. Johannesburg: University of Johannesburg.

Ngatane, N. (2019). Makhura vows to equip young people with skills for 4th Industrial Revolution. https://ewn.co.za/2019/07/02/makhura-vows-to-equip-young-people-with-skills-for-4th-industrial-revolution

Ogunlela, O., \& Tengeh, R. (2021). The fourth industrial revolution and the future of entrepreneurial university in South Africa. International Journal of Research in Business and Social Science, 10(3), 91-100. https://doi.org/10.20525/ijrbs.v10i3.1103

Pillay, C. (2005). Gauteng`s largest Metro, Ekurhuleni, with partner BTN standardises network on Cisco. https://www.itweb.co.za/content/nWJad7baRLGvbjO1

Republic of South Africa. (1996). Constitution of the Republic of South Africa, 1996. Pretoria: Government printer.

Republic of South Africa. (1998). Local Government: Municipal Structures Act, No. 117 of 1998. Pretoria: Government printer.

Republic of South Africa, (1998). Skills Development Act 97. Pretoria: Government Printer.

RSA: Department of Communications and Digital Technologies (DCDT). (2021). PC4IR Strategic Implementation Plan (PC4IR SIP). Pretoria: DCDT.

Ringo, T., Schweyer, A., DeMarco, M., Jones, R., \& Lesser, E. (2008). Integrated Talent Management: Part 1 - Understanding the Opportunities for Success, IBM, Somers, NY.

Sebola, M. P. (2015). Scarce skills expatriates in South Africa Universities: Rhetoric and realities of the "Messianic" academics. Journal for Transdisciplinary Research in Southern Africa, 11(4), 180-192.

Schwab, K. (2016). The Fourth Industrial Revolution: What It Means, How to Respond, January $14,2016$. https://www.weforum.org/agenda/2016/01/the-fourth-industrialrevolution-what-it-means-and-how-to-respond.

Schultz, T.W. (1961). Investment in Human Capital. American Economic Review, 51, 1-17.

Schultz, T.W. (1981). Investing in people: The economics of population quality. Los Angeles: The University of California Press.

Shava, E., \& Maramura. T.C. (2016). A Descriptive Analysis of the Causes, Challenges and Effects of Skills Deficit on Youth Empowerment in South Africa. Journal of Social Sciences, 49(1-2), 93-100. https://doi.org/10.1080/09718923.2016.118936.

Shava, E., \& Hofisi, C. (2017). Challenges and opportunities for public administration in the fourth industrial revolution. African Journal of Public Affairs, 9(9), 203-215.

Statistics South Africa (2015). Quarterly Labour Force Survey. Pretoria, South Africa: Government Printer.

Silzer, R., \& Dowell, B. (2010). Strategy-Driven Talent Management: A Leadership Imperative., San Francisco. John Wiley and Sons, Inc. Jossey-Bass.

Software, A.G. (2013). Ekurhuleni Municipality receives global award for ICT innovation. http://pressoffice.itweb.co.za/softwareAG/PressRelease.php?StoryID=243821

South African Local Government Association (SALGA). (2018). Municipal Managers Forum. Pretoria: SALGA.

South African Local Government Association (SALGA). (2020). 2nd Annual Local Government Talent Management Seminar. Pretoria: SALGA.

Sutcliffe, M., \& Bannister, S. (2020). Research on the 4th Industrial Revolution: Implications for Local government in the context of Skills Development Final Report.

Sutherland, E. (2019). The Fourth Industrial Revolution - The Case of South Africa. Politikon, 1-20. https://doi.org/10.1080/02589346.2019.169600

Tetik, S. (2016). Talent Management: A Review of Theoretical Perspectives and a Guideline for Practioners. Nile Journal of Business and Economics, 4, 40-56. https://doi.org/10.20321/nilejbe.v2i4.77

The Presidency. (2021). Presidential Commission on 4IR presents recommendations to President Ramaphosa. Pretoria: The Presidency.

Thunnissen, M. (2016). Talent management: For what, how and how well? An empirical exploration of talent management in practice, Employee Relations, 38 (1),57-72. https://doi.org/10.1108/ER-08-2015-0159

Todaro, M. (2011). Development economics. England: Pearson Education Ltd. 
University of the Witwatersrand. (2019a). Wits at the forefront of the technology revolution. https://www.wits.ac.za/ University of the Witwatersrand. (2019b). Fak'ugesi and Smart City Office - a natural fit, https://www.wits.ac.za/

Van Dijk, H.G. (2008). Administration vs. talent: the administrative context for talent management, Journal of Public Administration, 44(3.1), 520-530.

Van Dyk, J., Coetzee, M., \& Tebele, C. (2013). Organisational Commitment and Job Embeddedness of Service Staff with Critical and Scarce Skills. South African Journal of Labour Relations, 37(1), 61-78.

Veladat, F., \& Navehebrahim, A. (2017). Designing a model for managing talents of students in elementary school: A qualitative study based on grounded theory. Procedia - Social and Behavioral Sciences, 29, 1052-1060. https://doi.org/j.sbspro.2011.11.338

Walker, A. (2019). Makhura: Gauteng to become a 'hub of Fourth Industrial Revolution' skills. https://memeburn.com/

XPATWEB (2021). Highlight of Critical Skills Survey Results 2020/21. https://www.xpatweb.com/2020-2021-critical-skills-surveyresults/

Publisher's Note: SSBFNET stays neutral with regard to jurisdictional claims in published maps and institutional affiliations.

\section{(1) (1)}

(C) 2021 by the authors. Licensee SSBFNET, Istanbul, Turkey. This article is an open access article distributed under the terms and conditions of the Creative Commons Attribution (CC BY) license (http://creativecommons.org/licenses/by/4.0/).

International Journal of Research in Business and Social Science (2147-4478) by SSBFNET is licensed under a Creative Commons Attribution 4.0 International License. 